\title{
Syntheses and crystal structures of diiminosuccinonitrile and its iron(II) complex
}

\author{
Chin-Ti Chen, Der-Shin Liaw, Gene-Hsiang Lee, Shie-Ming Peng* \\ Department of Chemistry, National Taiwan University, Taipei, Taiwan, 10764
}

A series of metal complexes with diiminosuccinonitrile (disn) (3) and diiminosuccinonitrile radical anion (s-disn)

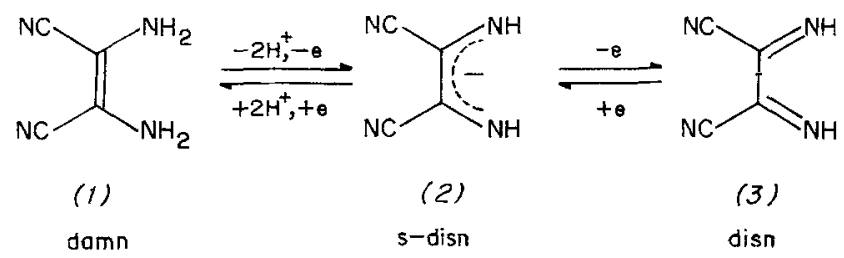

(2), have been described ${ }^{(1-6)}$. Miles et $a^{(1)}$, have reported the preparation of neutral $\mathrm{Ni}^{\mathrm{II}}, \mathrm{Pd}^{\mathrm{II}}$, and $\mathrm{Pt}^{\mathrm{II}}$ complexes with (2). Improved synthetic methods for the preparations of the above complexes and the molecular structure of [Pt(s-disn $\left.)_{2}\right]$ have been reported by Lauher et $a l^{(2)}$. We have described the synthesis and reactions of cobalt complexes with (2) and the molecular structure of $\left[\mathrm{Co}^{\mathrm{III}}(\mathrm{CN})(\mathrm{s}-\mathrm{disn})_{2}\right]^{(3)}$. A series of interesting structures $\left[\mathrm{Ni}(\mathrm{s}-\mathrm{disn})_{2}\right],\left[\mathrm{Co}_{2}(\mathrm{~s}-\mathrm{disn})_{4}\right],\left[\mathrm{As}(\mathrm{Ph})_{4}\right]\left[\mathrm{Co}(\mathrm{s}-\mathrm{disn})_{2}\right]$, $\left[\mathrm{RuCl}_{2}\left(\mathrm{CH}_{3} \mathrm{CN}\right)_{2}\right.$ (disn) $]$ have been also determined by us $^{(4-6)}$. The redox-reaction of $\mathrm{Cu}^{\text {II }}$ with (1), damn, has also been studied ${ }^{(7)}$. In continuation of previous investigations in this area, we report the syntheses and the crystal structures of $\alpha$-diimine ligand (3) and its iron(II) complexes.

Diiminosuccinonitrile (disn) was synthesized by the oxidation of damn with dichlorodicyanobenzoquinone ${ }^{(8)}$.

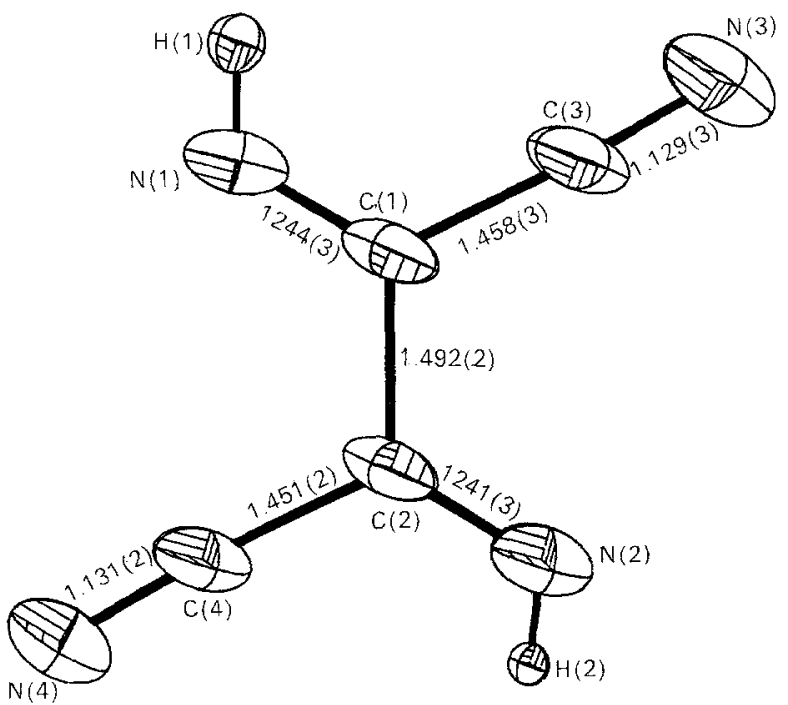

Figure 1. ORTEP plot of (3), unbound disn.

\footnotetext{
* Author to whom all correspondence should be directed. Also from: Institute of Chemistry, Academia Sinica, Nankang, Taipei, Taiwan, 11529, Republic of China
}

Colourless crystals suitable for single $x$-ray analysis were obtained by sublimation. The structure of disn, (3), is shown in Figure $1^{(9)}$. All the non-hydrogen atoms form a least-square plane with the maximum deviations $-0.040 \AA$ for $\mathrm{N}(1)$ and $0.047 \AA$ for $\mathrm{N}(4)$. The $\mathrm{C}(1)-\mathrm{N}(1)$ and $\mathrm{C}(2)-\mathrm{N}(2)$ bonds are double bonds $(1.244(3)$ and $1.241(3) \AA$, respectively) while the $\mathrm{C}(3)-\mathrm{N}(3)$ and $\mathrm{C}(4)-$ $\mathrm{N}(4)$ bonds are triple bonds $(1.129(3)$ and $1.131(2) \AA$, respectively). The remaining $\mathrm{C}-\mathrm{C}$ bonds are single bonds.

The reaction of iron(II) perchlorate with disn in alcoholic solution results immediately in the formation of the deep blue tris-(disn) iron(II) complex which is too unstable to isolate. After complex reactions which take a few days addition of $\mathrm{Et}_{2} \mathrm{O}$ to the solution leads to the isolation of the blue complex, $(5)^{(10)}$.

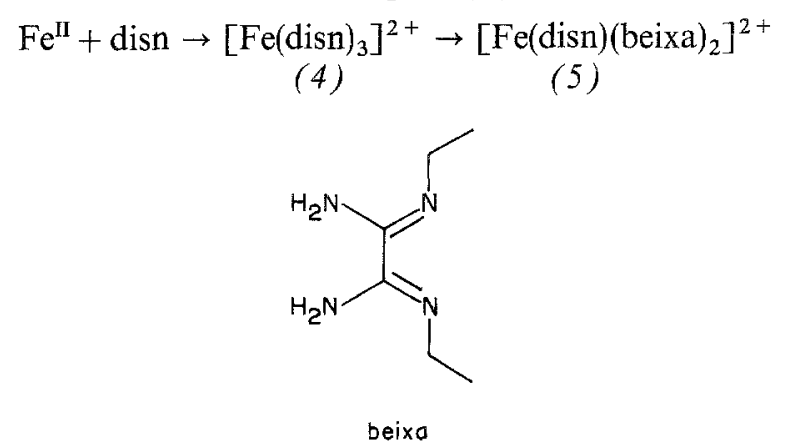

Suitable single crystals were obtained by slow diffusion of diethyl ether into a ethyl alcohol solution of $\mathrm{Fe}^{\mathrm{II}}$ (disn)(beixa) $\left.{ }_{2}\right]\left(\mathrm{ClO}_{4}\right)_{2}$.

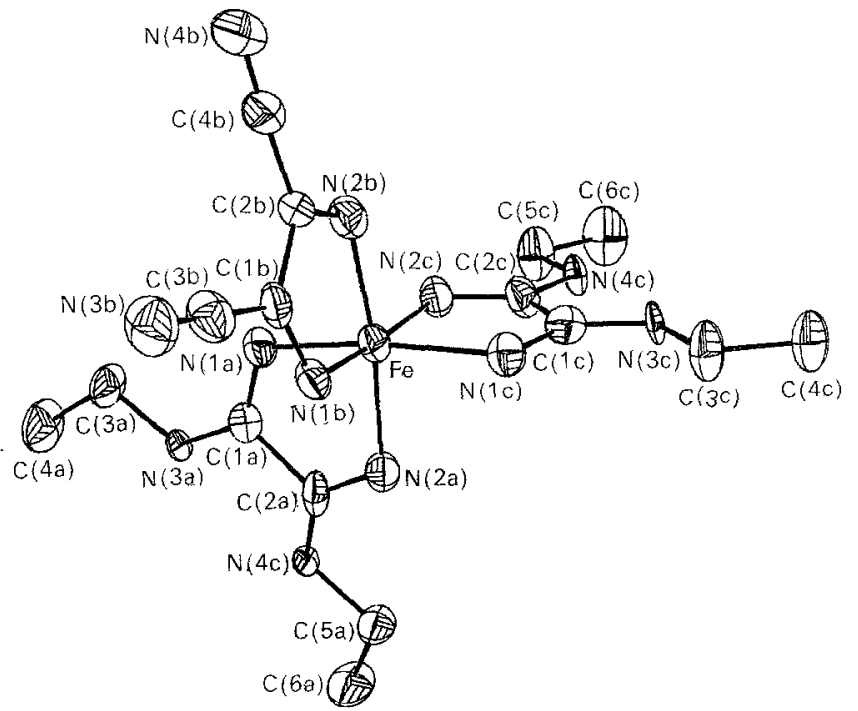

Figure 2. ORTEP plot of the (5) $\left[\mathrm{Fe}(\text { disn) (beixa) })_{2}\right]^{2+}$ cation. 
Table 1. Bond lengths $(\AA)$ and bond angles $\left({ }^{\circ}\right)$.

\begin{tabular}{|c|c|c|c|}
\hline $\mathrm{Fe}-\mathrm{N}(1 \mathrm{a})$ & $1.966(8)$ & $N(1 c)-C(1 c)$ & $1.317(14)$ \\
\hline $\mathrm{Fe}-\mathrm{N}(2 \mathrm{a})$ & $2.005(9)$ & $N(2 c)-C(2 c)$ & $1.325(14)$ \\
\hline $\mathrm{Fe}-\mathrm{N}(1 \mathrm{~b})$ & $1.871(8)$ & $N(3 c)-C(1 c)$ & $1.285(13)$ \\
\hline $\mathrm{Fe}-\mathrm{N}(2 \mathrm{~b})$ & $1.873(9)$ & $N(3 c)-C(3 c)$ & $1.425(15)$ \\
\hline $\mathrm{Fe}-\mathrm{N}(1 \mathrm{c})$ & $1.985(9)$ & $N(4 c)-C(2 c)$ & $1.250(14)$ \\
\hline $\mathrm{Fe}-\mathrm{N}(2 \mathrm{c})$ & $1.989(9)$ & $N(4 c)-C(5 c)$ & $1.440(15)$ \\
\hline$N(1 a)--C(1 a)$ & $1.319(14)$ & $C(1 a)-C(2 a)$ & $1.478(15)$ \\
\hline$N(2 a)-C(2 a)$ & $1.313(13)$ & $C(3 a)-C(4 a)$ & $1.447(17)$ \\
\hline$N(3 a)-C(1 a)$ & $1.286(12)$ & $C(5 a)-C(6 a)$ & $1.478(17)$ \\
\hline $\mathrm{N}(3 \mathrm{a})-\mathrm{C}(3 \mathrm{a})$ & $1.438(14)$ & $C(1 b)-C(2 b)$ & $1.435(15)$ \\
\hline $\mathrm{N}(4 \mathrm{a})-\mathrm{C}(2 \mathrm{a})$ & $1.269(13)$ & $C(1 b)-C(3 b)$ & $1.426(15)$ \\
\hline$N(4 a)-C(5 a)$ & $1.424(15)$ & $C(2 b)-C(4 b)$ & $1.445(16)$ \\
\hline$N(1 b)-C(1 b)$ & $1.302(13)$ & $C(1 c)-C(2 c)$ & $1.492(16)$ \\
\hline$N(2 b)-C(2 b)$ & $1.315(14)$ & $C(3 c)-C(4 c)$ & $1.461(16)$ \\
\hline$N(3 b)-C(3 b)$ & $1.109(15)$ & $C(5 c)-C(6 c)$ & $1.419(18)$ \\
\hline$N(4 b)-C(4 b)$ & $1.130(16)$ & & \\
\hline $\mathrm{N}(1 \mathrm{a})-\mathrm{Fe}-\mathrm{N}(2 \mathrm{a})$ & $79.3(4)$ & $N(1 a)-C(1 a)-N(3 a)$ & $128.8(10)$ \\
\hline $\mathrm{N}(1 \mathrm{a})-\mathrm{Fe}-\mathrm{N}(1 \mathrm{~b})$ & $91.6(4)$ & $N(1 a)-C(1 a)-C(2 a)$ & $113.9(9)$ \\
\hline $\mathrm{N}(1 \mathrm{a})-\mathrm{Fe}-\mathrm{N}(2 \mathrm{~b})$ & $92.5(4)$ & $N(3 a)-C(1 a)-C(2 a)$ & $117.3(9)$ \\
\hline $\mathrm{N}(1 \mathrm{a})-\mathrm{Fe}-\mathrm{N}(1 \mathrm{c})$ & $166.8(4)$ & $N(2 a)-C(2 a)-N(4 a)$ & $131.0(9)$ \\
\hline $\mathrm{N}(1 \mathrm{a})-\mathrm{Fe}-\mathrm{N}(2 \mathrm{c})$ & $92.0(4)$ & $N(2 a)-C(2 a)-C(1 a)$ & $113.3(9)$ \\
\hline $\mathrm{N}(2 \mathrm{a})-\mathrm{Fe}-\mathrm{N}(1 \mathrm{~b})$ & $95.2(3)$ & $N(4 a)-C(2 a)-C(1 a)$ & $115.7(9)$ \\
\hline$N(2 a)-F e-N(2 b)$ & $171.1(4)$ & $N(3 a)-C(3 a)-C(4 a)$ & $110.8(10)$ \\
\hline $\mathrm{N}(2 \mathrm{a})-\mathrm{Fe}-\mathrm{N}(1 \mathrm{c})$ & $90.4(3)$ & $N(4 a)-C(5 a)-C(6 a)$ & $108.2(9)$ \\
\hline $\mathrm{N}(2 \mathrm{a})-\mathrm{Fe}-\mathrm{N}(2 \mathrm{c})$ & $90.8(3)$ & $N(1 b)-C(1 b)-C(2 b)$ & $112.0(9)$ \\
\hline $\mathrm{N}(1 \mathrm{~b})-\mathrm{Fe}-\mathrm{N}(2 \mathrm{~b})$ & $81.5(4)$ & $N(1 b)-C(1 b)-C(3 b)$ & $124.7(10)$ \\
\hline$N(1 b)-F e-N(1 c)$ & $97.6(4)$ & $C(2 b)-C(1 b)-C(3 b)$ & $123.3(10)$ \\
\hline $\mathrm{N}(1 \mathrm{~b})-\mathrm{Fe}-\mathrm{N}(2 \mathrm{c})$ & $173.5(3)$ & $N(2 b)-C(2 b)-C(1 b)$ & $113.4(9)$ \\
\hline$N(2 b)-F e-N(1 c)$ & $98.2(4)$ & $N(2 b)-C(2 b)-C(4 b)$ & $123.9(10)$ \\
\hline $\mathrm{N}(2 \mathrm{~b})-\mathrm{Fe}-\mathrm{N}(2 \mathrm{c})$ & $93.0(4)$ & $C(1 b)-C(2 b)-C(4 b)$ & $122.7(10)$ \\
\hline $\mathrm{N}(1 \mathrm{c})-\mathrm{Fe}-\mathrm{N}(2 \mathrm{c})$ & $79.7(4)$ & $N(3 b)-C(3 b)-C(1 b)$ & $176.5(13)$ \\
\hline $\mathrm{Fe}-\mathrm{N}(1 \mathrm{a})-\mathrm{C}(1 \mathrm{a})$ & $117.0(7)$ & $N(4 b)-C(4 b)-C(2 b)$ & $178.8(12)$ \\
\hline $\mathrm{Fe}-\mathrm{N}(2 \mathrm{a})-\mathrm{C}(2 \mathrm{a})$ & $116.2(7)$ & $N(1 c)-C(1 c)-N(3 c)$ & $129.2(10)$ \\
\hline$C(1 a)-N(3 a)-C(3 a)$ & $118.8(8)$ & $N(1 c)-C(1 c)-C(2 c)$ & $114.2(10)$ \\
\hline$C(2 a)-N(4 a)-C(5 a)$ & $117.1(8)$ & $N(3 c)-C(1 c)-C(2 c)$ & $116.6(9)$ \\
\hline $\mathrm{Fe}-\mathrm{N}(1 \mathrm{~b})-\mathrm{C}(1 \mathrm{~b})$ & $117.2(7)$ & $N(2 c)-C(2 c)-N(4 c)$ & $131,3(10)$ \\
\hline $\mathrm{Fe}-\mathrm{N}(2 \mathrm{~b})-\mathrm{C}(2 \mathrm{~b})$ & $115.8(7)$ & $N(2 c)-C(2 c)-C(1 c)$ & $112.8(10)$ \\
\hline $\mathrm{Fe}-\mathrm{N}(1 \mathrm{c})-\mathrm{C}(\mathrm{lc})$ & $116.4(7)$ & $\mathrm{N}(4 \mathrm{c})-\mathrm{C}(2 \mathrm{c})-\mathrm{C}(1 \mathrm{c})$ & $115.9(9)$ \\
\hline $\mathrm{Fe}-\mathrm{N}(2 \mathrm{c})-\mathrm{C}(2 \mathrm{c})$ & $116.8(7)$ & $N(3 c)-C(3 c)-C(4 c)$ & $108.1(10)$ \\
\hline$C(1 c)-N(3 c)-C(3 c)$ & $119.5(8)$ & $N(4 c)-C(5 c)-C(6 c)$ & $109.1(10)$ \\
\hline$C(2 c)-N(4 c)-C(5 c)$ & $116.6(9)$ & & \\
\hline
\end{tabular}

Table 2. Comparison of bond distances $(\AA)$ and angles $\left(^{\circ}\right)$ between $(1),(2),(3)$ and their metal complexes.

\begin{tabular}{lccccc}
\hline & $(1)$, damn $^{(12)}$ & Ni(s-disn) ${ }_{2}^{(4)}$ & Pt(s-disn) ${ }_{2}^{(2)}$ & $(3)$, disn & $(5),\left[\text { Fe(disn) }(\text { beixa })_{2}\right]^{2+}$ \\
\hline $\mathrm{M}-\mathrm{N}(1)$ & & $1.827(4)$ & $1.957(8)$ & - & $1.872(9)$ \\
$\mathrm{N}(1)-\mathrm{C}(1)$ & $1.392(8)$ & $1.330(4)$ & $1.323(13)$ & $1.242(3)$ & $1.308(14)$ \\
$\mathrm{C}(1)-\mathrm{C}(1)$ & $1.363(6)$ & $1.403(5)$ & $1.416(19)$ & $1.492(2)$ & $1.435(15)$ \\
$\mathrm{C}(1)-\mathrm{C}(2)$ & $1.439(7)$ & $1.443(5)$ & $1.415(15)$ & $1.454(3)$ & $1.435(16)$ \\
$\mathrm{C}(2)-\mathrm{N}(3)$ & $1.165(10)$ & $1.135(5)$ & $1.123(15)$ & $1.130(3)$ & $1.120(16)$ \\
$\mathrm{N}(1)-\mathrm{M}-\mathrm{N}(1)$ & - & $84.3(1)$ & $79.1(5)$ & - & $81.5(4)$ \\
$\mathrm{M}-\mathrm{N}(1)-\mathrm{C}(1)$ & & $114.6(2)$ & $116.4(7)$ & - & $116.5(7)$ \\
$\mathrm{N}(1)-\mathrm{C}(1)-\mathrm{C}(1)$ & $124.1(4)$ & $113.2(3)$ & $114.0(6)$ & $120.6(1)$ & $112.7(9)$ \\
$\mathrm{N}(1)-\mathrm{C}(1)-\mathrm{C}(2)$ & $117.6(3)$ & $124.4(3)$ & $122.6(9)$ & $124.5(1)$ & $124.3(10)$ \\
$\mathrm{C}(1)-\mathrm{C}(1)-\mathrm{C}(2)$ & $118.1(8)$ & $122.4(3)$ & $123.3(7)$ & $115.0(1)$ & $123.0(10)$ \\
$\mathrm{C}(1)-\mathrm{C}(2)-\mathrm{N}(3)$ & $179.8(9)$ & $177.8(4)$ & $179.7(13)$ & $175.8(2)$ & $177.6(13)$ \\
\hline
\end{tabular}

The results of the $\mathrm{x}$-ray structural analysis of (5), shown in Figure $2^{(11)}$, indicate that the central iron atom has a trigonally distorted octahedral coordination. The disn ligand is planar with maximum deviation from the least-square plane of $0.035 \AA$. The extremely short ironnitrogen(disn) distances (av. 1.872(9) $\AA$, Table 1) indicate very strong binding between the low-spin iron(II) and the disn. Further evidence of the strong $\mathrm{Fe}-\mathrm{N}$ binding is the lengthening of the $\alpha$-diimine bonds. $(1.309(14) \AA$ for the disn ligand in the complex and 1.243(3) $\AA$ in the free state). It is attributed to back donation from the filled d-orbitals to the $\pi^{*}$-orbitals of the $\alpha$-diimine ligand. The comparison of bond parameters between (1), (2), (3) and their metal complexes are tabulated in Table 2 . The beixa ligands also form good least-square planes with maximum deviation of $0.042 \AA$. The four $\mathrm{C}=\mathrm{N}$ bonds [C(1a)-N(3a), C(2a)- 
$\mathrm{N}(4 \mathrm{a}), \mathrm{C}(1 \mathrm{c})-\mathrm{N}(3 \mathrm{c})$, and $\mathrm{C}(2 \mathrm{c})-\mathrm{N}(4 \mathrm{c})$, av. 1.273(14) $\AA]$ are short, consistent with the proposed structure.

It is still not clear that how disn transforms to beixa in the alcoholic solution. We are currently attemping to isolate $\left[\mathrm{Fe}(\operatorname{disn})_{3}\right]^{2+}$ and clarified the chemical transformation of disn to beixa.

\section{Acknowledgements}

We thank the National Research Councils of the Republic of China for support.

\section{References}

${ }^{(1)}$ M. G. Miles, M. B. Hursthouse and A. G. Robinson, J. Inorg. Nucl. Chem., 33, 2015 (1971).

${ }^{(2)}$ J. W. Lauher and J. A. Ibers, Inorg. Chem., 14, 640 (1975).

${ }^{(3)}$ S. M. Peng, Y. Wang, S. Wang, M. Chung, Y. LePage and E. Gabe, J. Chem. Soc., Chem. Comm., 329 (1981).

${ }^{(4)}$ S. M. Peng, Y. Wang and C. K. Chiang, Acta Crystallogr., Sect. C, 40, 1541 (1984).

${ }^{(5)}$ S. M. Peng, K. Peters E. Peters and A. Simon, Inorg. Chim. Acta, 101, L35 (1985).

${ }^{(6)}$ S. M. Peng, K. Peters, E. Peters and A. Simon, Inorg. Chim. Acta, 101, L35 (1985).

(7) S. M. Peng and D. S. Liaw, Inorg. Chim. Acta, 113, L11 (1986).

${ }^{(8)}$ R. W. Begland, A. Cairncross, D. S. Donald, D. R. Hartter, W. A. Sheppard and O. W. Webster, J. Am. Chem. Soc., 93, $4953(1971)$

(9) A colourless crystal of dimensions $0.2 \times 0.2 \times 0.4 \mathrm{~mm}$ was used for data collection. Diffractometer data were collected on a CAD4 diffractometer using graphite-monochromated MoK radiation. Unit cell dimensions were determined from a least squares refinement of 25 reflections $\left(18.20^{\circ}<2 \theta\right.$ $<24.12^{\circ}$ ). Formula: $\mathrm{C}_{4} \mathrm{~N}_{4} \mathrm{H}_{2}$, formula weight: 106.05 , absorption coefficient: $0.09 \mathrm{~mm}^{-1}$, space group: $\mathrm{P}$ cab, $a=7.535(1), \quad b=9.865(1), c=13.428(5) \AA, V=998.12 \AA^{3}$, $Z=8$. Intensity data within $2 \theta<60^{\circ}$ were collected at various scan speed of $20 / 16$ to $20 / 3^{\circ} / \mathrm{s}$ by using the $\omega-2 \theta$ scan techniques, with a scan range calculated according to the expression $0.8+0.35 \tan \theta$. The three intensity monitors were checked every 2 hours and fluctucated randomly within $2 \%$ over the entire data collection. After data collection, the intensities were reduced to $\mathrm{F}$ and $\sigma(\mathrm{F})$ according to counting statistics, and the weights were assigned as $\mathrm{w}=1 / \sigma^{2}(\mathrm{~F})$ $+0.0001 \mathrm{~F}^{2}$. Of the 1452 unique reflections, 662 having I $>2 \sigma(1)$, were consider observed. All calculations were carried out on a PDP-11/23 computer, using the NRCC SDP PDP-11 package, MULTAN and the ORTEP from the Enraf-Nonius SDP. Atomic scattering factors were obtained from the international tables for $x$-ray crystallography (1974). The structure was solved by a direct method using
MULTAN with 200 highest E's, 100 smallest E,'s and 3639 $\sigma-2$ phase relationships. The final least-squares cycle with anisotropic thermal parameters for all nonhydrogen atoms and isotropic thermal parameters for all hydrogen atoms, gave $\mathrm{R}$ and $\mathrm{Rw}$ factors, respectively, of 5.0 and $5.4 \%$. Atomic coordinates, displacement factor coefficients, full lists of bond lengths and angles and lists of $\mathrm{Fo} / \mathrm{Fc}$ values have been deposited as supplementary data with Editor, from whom copies are available on request. Atomic coordinates have also been deposited with the Cambridge Crystallographic Data Centre.

${ }^{(10)}$ In the preparation, disn (318 $\mathrm{mg}$ in $\left.30 \mathrm{~cm}^{3} \mathrm{EtOH}\right)$ and $\mathrm{Fe}\left(\mathrm{ClO}_{4}\right)_{2} \cdot 6 \mathrm{H}_{2} \mathrm{O}\left(363 \mathrm{mg}\right.$ in $\left.25 \mathrm{~cm}^{3} \mathrm{EtOH}\right)$ were mixed together. The deep shining blue solution which immediately formed became dark blue gradually. After one to two days, addition of $\mathrm{Et}_{2} \mathrm{O}$ to the dark blue solution led to the precipitation of blue product (5) (50 $\mathrm{mg}, 8 \%$ yield).

(11) A deep blue crystal of dimensions $0.12 \times 0.15 \times 0.34 \mathrm{~mm}$ was used for data collection. Unit cell dimensions were determined from a least-squares refinement of 25 reflections $\left(19.02^{\circ}<2 \theta<21.4^{\circ}\right)$. Formula: $\mathrm{FeN}_{12} \mathrm{C}_{16} \mathrm{H}_{31} \mathrm{Cl}_{2} \mathrm{O}_{9}$, for mula weight: 662.02 , absorption coefficient: $0.77 \mathrm{~mm}^{-1}$, space group: $\mathrm{P} \quad 21 / \mathrm{n}, \quad a=8.519(1), \quad b=30.270(7)$, $c=11.701(2) \AA, \alpha=107.02(6)^{\circ}, V=2885.2 \AA^{3}, Z=4$, Intensity data within $2 \theta<50^{\circ}$ were collected at various scan speed of $20 / 22$ to $20 / 3^{\circ} / \mathrm{S}$ by using the $\omega-2 \theta$ scan techniques, with a scan range calculated according to the expression 0.6 $+0.35 \tan \theta .4901$ unique reflections were measurement 2397 having $\mathrm{I}>3 \sigma(\mathbf{I})$ were consider observed. All calculations were carried out on a VAX-785 computer, using the NRCC SDP VAX package. The structure was solved by the heavy atom method. The final least-squares cycle with anisotropic thermal parameters for all nonhydrogen atoms and fixed contribution for hydrogen atoms gave $\mathrm{R}$ and $\mathrm{Rw}$ factors respectively of 8.6 and $6.8 \%$. Other details are the same as in (9)

${ }^{12)}$ B. R. Penford and W. N. Lipscomb, Acta Cryst., 14, 589 (1961).

(Received 9 February 1988)

TMC $1844(\mathrm{C})$ 